\title{
HOW TRADE COMPOS
AFFECTS SENSITIVITY \\ TO FOREIGN SHOCKS: \\ APPLYING A GLOBAL VAR MODEL TO UKRAINE'
}

\author{
OLEKSANDR FARYNA ${ }^{\mathrm{ab}}$, HELI SIMOLA ${ }^{\mathrm{c}}$ \\ ${ }^{a}$ National Bank of Ukraine, Kyiv, Ukraine \\ ${ }^{b}$ National University of Kyiv-Mohyla Academy, Kyiv, Ukraine \\ E-mail: oleksandr.faryna@bank.gov.ua \\ 'The Bank of Finland Institute for Economies in Transition, BOFIT, Helsinki, Finland \\ E-mail: heli.simola@bof.fi
}

Abstract This paper studies the transmission of foreign output shocks to real activity in Ukraine through international trade. We employ a global vector auto regressive (GVAR) model that captures about $80 \%$ of the world economy and incorporates time-varying trade and financial weights. According to our estimates, a mild recession in the US of a $1 \%$ drop in output generates a substantial recession in Ukraine of about $2.2 \%$. A similar drop of output in the euro area and Russia translates to a drop in output of about $1.7 \%$ in Ukraine. Finally, the same drop of output in CEE, China, or the CIS leads to an output decline of about $0.4 \%$ in Ukraine. Meanwhile, Ukraine's response to euro area output shock has been steadily increasing over the last couple of decades due to changes in global trade flows. Ukraine's sensitivity to shocks in the US and euro area is notably strengthened by indirect trade effects, while the response to shocks from emerging economies, i.e., China, CEE, the CIS, and partially Russia, is mainly determined by bilateral trade linkages.

JEL Codes C32, F42, F43, E32

Keywords Ukraine, global VAR, foreign shocks, trade compositions

\section{INTRODUCTION}

Over last few decades, Ukraine has been rapidly integrating with the global economy through trade and financial linkages. Moving from central planning to a market economy and going through a set of internal reforms, Ukraine became a small and very open emerging economy, with about $100 \%$ international merchandise trade to GDP. ${ }^{2}$ Being an energy importing economy, Ukraine's major export goods are commodities as well - e.g. agricultural goods, metals, etc. This high degree of openness together with considerable dollarization of the economy makes Ukraine particularly sensitive to foreign shocks and vulnerabilities in global markets.

For over 25 years, Ukraine followed a fixed exchange rate regime that was intended to protect the economy from adverse external shocks. However, in 2015 after several dramatic currency crises and recessions, the National Bank of Ukraine gave up fixing the exchange rate and switched its policy framework to an inflation targeting regime, at the same time declaring its commitment to ensure price and financial stability, see Lepushynskyi (2015). A flexible exchange rate, on the one hand, can partially absorb foreign shocks and mitigate their effect on the real economy. On the other hand, the degree of exchange rate pass-through to domestic prices in Ukraine remains high ${ }^{3}$ and, hence, foreign factors may play an important role in shaping macroeconomic developments. For this reason, economic stabilization policies require a thorough understanding of the degree and determinants of Ukraine's sensitivity to international shocks.

International trade is one of the most important channels through which external shocks from foreign countries are transmitted to a small open economy. Historically, Ukraine had tight trade linkages with the euro area, Russia, and the countries of Central and Eastern Europe (CEE) and the Commonwealth of Independent States (CIS). Figure 1 shows the trade composition (exports and imports of goods) of Ukraine with major trading partners over the last few

\footnotetext{
${ }^{1}$ The opinions and conclusions in the paper are strictly those of authors and do not necessarily reflect the views of their affiliated institutions.

${ }^{2}$ According to the World Bank database.

${ }^{3}$ Faryna (2016b) estimates the degree of exchange rate pass-through in Ukraine to be 0.3-0.4, which is relatively high compared to other emerging economies.

(c) National Bank of Ukraine, O. Faryna, H. Simola, 2019. This work is licensed under a Creative Commons Attribution-NonCommercial 4.0 International License. Avaliable at https://doi.org/10.26531/vnbu2019.247.01
} 
decades. In the early 2000s, Ukraine's major trading partner was Russia, with a trade share of about $40 \%$ due to tight linkages in production and common supply chains persisting since the time of the Soviet Union. The euro area was the second largest trading partner of Ukraine, with a trade share of about $30 \%$. These shares had been slightly decreasing ahead of the 2008 global financial crisis (to 30\% and 20\% for Russia and the euro area, respectively) and Ukraine has since been increasing its trade with other emerging economies. After the global financial crisis, which had a particularly strong effect on Ukraine's economy, Ukraine rapidly increased its trade with Russia in line with the pro-Russian economic policy of the Ukrainian government. Due to the geopolitical conflict with Russia in 2014, Russian trade dropped to about $20 \%$, while Ukraine shifted its trade to the euro area and CEE economies. Meanwhile, China increased its share in Ukraine's trade structure from $3 \%$ to more than $10 \%$.

The existing literature provides empirical evidence that Ukraine is sensitive to foreign shocks and that cross-country spillover effects are considerable and significant. Several studies examine the transmission of foreign output shocks to Ukraine within the CIS region. Feldkircher (2015) finds that the US and euro area play a dominant role for the region and for Ukraine in particular. Meanwhile, as argued in Feldkircher \& Korhonen (2014), the sensitivity to emerging economies (e.g., China) remains moderate, but is stronger compared to other countries. The importance of the Russian economy for Ukraine is confirmed in Alturki et al. (2009). Faryna \& Simola (2018) also report a high sensitivity to US, euro area, Russian, and Chinese output shocks. In addition, several studies provide evidence for the importance of the CIS region in inflation and exchange rate developments, see Comunale \& Simola (2018), Faryna (2016a), Beckmann \& Fidrmuc (2013), and Dreger \& Fidrmuc (2011).
In the new globalized world, where all countries have tight trade linkages, country-specific foreign shocks can amplify the response of an economy through high-order transmission channels. The analysis of the sensitivity of an economy to external shocks, therefore, should take into account the multilateral perspective of the world economy. In this paper, we develop a framework to analyze the sensitivity of Ukraine to foreign shocks from its major trading partners, and how this sensitivity has evolved during the 2000s. In addition, we examine the importance of direct and indirect channels in the propagation of these shocks. We employ a global vector auto regressive (GVAR) model, which includes major macroeconomic variables for 30 economies linked together by trade and financial relationships. The GVAR model in this paper is almost identical to the one in Faryna \& Simola (2018), which studies the transmission of international output shocks to the CIS region. Our version of the GVAR model, however, includes a different specification for the Ukrainian individual model, since our focus is a single economy.

First, we develop a GVAR model and evaluate its ability to replicate the propagation of various shocks to the Ukrainian economy. For this purpose, we conduct a bootstrap simulation to test the significance of Ukraine's response to domestic output, foreign output, and oil price shocks. The GVAR model gives reasonable results, although with limited statistical significance. Meanwhile, the response to a global output shock remains statistically significant, indicating that the GVAR model can be a useful tool for exploring the response of the Ukrainian economy to foreign output shocks.

Second, we analyze the sensitivity of Ukrainian economy to country-specific foreign shocks and the evolution of this

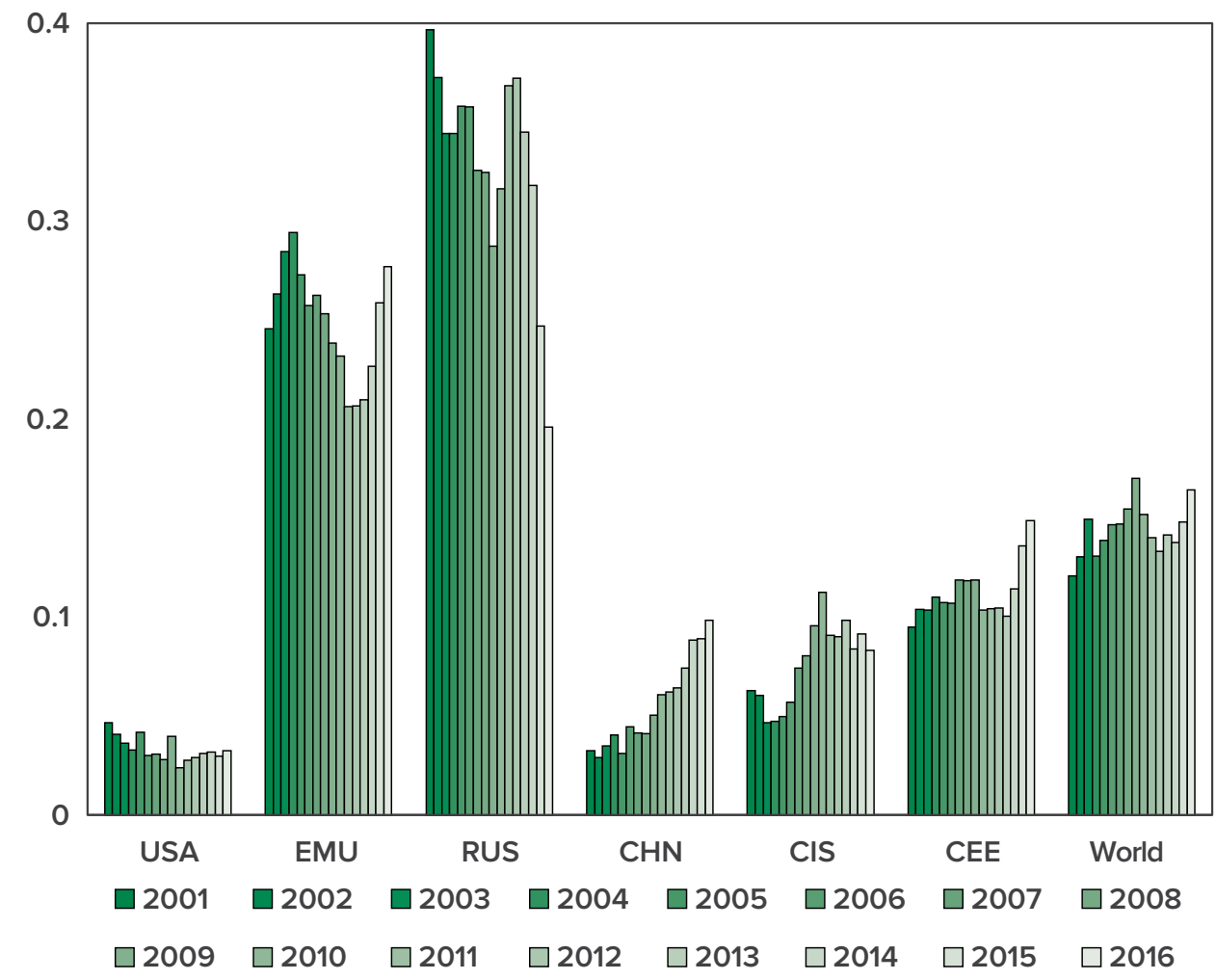

Figure 1. Evolution of Trade Composition in Ukraine.

Note: trade composition is computed using statistics on exports and imports in US dollars from IMF DOTS 
sensitivity over time, as global trade linkages have changed considerably over the last few decades. We compute timevarying responses of Ukrainian output to country-specific output shocks in the US, the euro area, Russia, China, and the CEE and $\mathrm{CIS}$ regions to explore how those responses evolve over time. Our general findings suggest that the Ukrainian economy is highly sensitive to foreign shocks, especially in the US, the euro area, and Russia. According to our estimates, a mild recession in the US of a $1 \%$ drop in output generates a substantial recession in Ukraine, with a drop in output of about $2.2 \%$. A similar $1 \%$ drop in output in the euro area and Russia translates to a drop of output in Ukraine of about $1.7 \%$. Finally, the same drop of output in the CEE area, China, or CIS leads to a decline in output of about $0.4 \%$ in Ukraine. The response of the Ukrainian economy to euro area and CEE shocks has been steadily increasing over last couple of decades, whereas it has been slightly decreasing with regard to US and Russian shocks.

Lastly, we analyze how Ukraine's sensitivity to countryspecific shocks depends on whether the propagation channels are direct and indirect. In particular, our analysis provides insights on the importance of indirect effects. For this purpose, we solve the model under counterfactual scenarios for Ukraine's trade composition and explore how bilateral trade with a specific country amplifies or counteracts the responses of the Ukrainian economy to foreign shocks. We find that Ukraine's sensitivity to output shocks in the US and in the euro area remains high even if the direct bilateral trade channel is disabled, indicating that even the indirect effects from these shocks are very important for the Ukrainian economy. The response to Russian output shocks also remains strong in counterfactual scenarios due to indirect trade channels, although it is slightly lower than due to the direct trade channel. Foreign shocks to the CEE and $\mathrm{CIS}$ regions have a much stronger effect through the direct trade channel. Finally, the propagation of Chinese output shocks through indirect trade channels is weak, indicating that Ukraine's trading partners and the global economy in general remain fairly resistant to macroeconomic developments in China. This is slightly surprising, but similar results have been reported in earlier literature. Thus, Ukraine's sensitivity to shocks in the $\mathrm{CEE}, \mathrm{CIS}$, and China are mainly defined by direct bilateral trade linkages.

This paper proceeds as following. In the second section, we briefly describe the global vector auto regressive model used for the analysis, with a particular focus on Ukraine. The third section provides results on i) the sensitivity of major Ukrainian macroeconomic variables to domestic and foreign shocks, ii) the evolution of responses to countryspecific foreign shocks over time due to changes in trade composition, and iii) counterfactual scenarios with alternative trade compositions. The fourth section concludes.

\section{GLOBAL VECTOR AUTO REGRESSIVE MODEL FOR UKRAINE}

In this section, we briefly describe the global vector auto regressive (GVAR) model used to study the transmission of international shocks to major Ukrainian macroeconomic variables. We employ the GVAR model developed in Faryna \& Simola (2018), which comprises 30 economies and covers about $80 \%$ of world PPP-GDP. However, given that our major focus is a single country, we pay more attention to the specification of the Ukrainian model within the GVAR, while the rest of the model is left unchanged.

Global VAR models have become popular for studying the dynamic transmission of shocks across countries, since they take into account high-order cross-county spillover effects from the multilateral perspective. ${ }^{4}$ They incorporate cross-country interdependencies, both static and dynamic, while solving the dimensionality issue. ${ }^{5}$ The GVAR model is presented in Pesaran, Schuermann \& Weiner (2004) and is further developed in Dees, di Mauro, Pesaran \& Smith (2007). Various studies employ GVAR models to explore crosscounty spillovers (see, for example, Galesi \& Lombardi, 2009; Harahap et al., 2016; Feldkircher, 2015; and Hajek \& Horvath, 2018).

The GVAR is a combination of individual country $\operatorname{VARX}^{*}\left(p_{i}, q_{i}\right)$ models that include domestic variables and weekly exogenous foreign and global variables:

$$
\Phi_{i}\left(L, p_{i}\right) X_{i t}=a_{i 0}+\Lambda_{i}\left(L, q_{i}\right) X_{i t}^{*}+\Psi_{i}\left(L, q_{i}\right) D_{t}+u_{i t},
$$

where $i=1,2,3, \ldots, N, N$ is the number of countries in the panel, $X_{i t}$ is a set of country-specific domestic variables; $X_{i t}^{*}$ is a set of country-specific foreign variables; $D_{t}$ is a set of common global variables; and $u_{i t}$ is a vector of structural countryspecific shocks. The lag order for domestic variables $p_{i}$ is assumed to be higher than the lag order for foreign and global variables $q_{i}$ to ensure the relative importance of domestic variables. Foreign variables are calculated as weighted averages of the corresponding domestic variables in other countries, $X_{i t}^{*}=\sum_{j=1}^{N} \omega_{i j} X_{j t}$, where $\omega_{i j}$ is a set of weights such that $\sum_{j=1}^{N} \omega_{i j}=1$. For example, foreign output for an individual country is calculated as the weighted average domestic output in the rest of the world, while weighting is based on bilateral trade flows between countries. Global variables, in turn, are usually estimated within individual country models (e.g., within the US individual model) or in a separate so-called dominant unit model which allows the inclusion of endogenous relationships between global variables and all countries in the panel. ${ }^{6}$

Each individual country model is estimated separately. Thereafter, individual models are combined through weight matrices $\omega_{i j}$ so that foreign variables for each country are linked to their domestic counterparts in other countries. After all of the models are linked together, the model is solved to compute Generalized Impulse Response Functions (GIRFs) ${ }^{7}$ in order to track how country-specific and variable-specific structural shocks transmit through the world's economies. For example, a shock to a specific variable in one country affects other domestic variables in this country, but also foreign variables in other countries with tight relationships. One of the most important advantages of GIRFs in GVARs is their ability to solve shock identification problems under

\footnotetext{
${ }^{4}$ The GVAR model is a type of Panel VAR model. Canova \& Ciccarelli (2013) provide a comprehensive overview of the empirical applications of Panel VAR models.

${ }^{5}$ Although they have major advantages, Panel VARs usually face several estimation problems. In particular, the large number of endogenous variables in the panel usually exceeds the number of observations in the sample. This problem is crucial for cross-county analysis, since the data availability for most emerging small open economies is limited. On the other side, a large number of cross-section units generates shock identification problems. Global VARs can solve those issues.

${ }^{6}$ See Chudik \& Pesaran (2013), Smith \& Yamagata (2011) for details.

${ }^{7}$ See Pesaran and Shin (1998) for details.
} 
several conditions. In particular, if cross-country residual correlation and country-specific serial residual correlation is low, GIRFs can be used to evaluate the response to countryspecific and variable-specific shocks.

In this paper, we utilize the model developed in Faryna \& Simola (2018) which, in turn, follows the approach described in Dees, di Mauro, Pesaran \& Smith (2007). ${ }^{8}$ The GVAR model includes 30 economies covering about $80 \%$ of world PPP-GDP. ${ }^{9}$ Each individual country model includes four domestic variables: consumer inflation, real output, the nominal short-term interest rate and real exchange rate for the period 2001Q1 - 2016Q4. The model also incorporates time-varying trade flows ${ }^{10}$ and financial linkages ${ }^{11}$ to compute foreign output and foreign interest rate variables, respectively. Oil prices are modeled in a dominant unit model, with PPP-adjusted GDP weights for determining the contribution of each country to oil price dynamics. A brief description of the model is presented in Table 1 (apart from the Ukrainian model).

Given that our major focus is a single economy - that of Ukraine - we pay additional attention to the specification of the individual Ukrainian model. Faryna \& Simola (2018) restrict the lag order for domestic, foreign, and global variables to unity due to the relatively short sample for a complex GVAR model. In this paper, however, we keep the structure of the global economy unchanged but increase the lag order for Ukrainian variables. We use the standard procedure of minimizing AIC to determine the lag order Thereafter, we conduct a set of diagnostic tests to check model adequacy. Table 2 reports summary results of tests of the specification of the individual Ukrainian model. The results of the diagnostic tests suggest that the model for Ukraine is stable and well specified.

\section{THE RESPONSE OF UKRAINE TO DOMESTIC AND FOREIGN SHOCKS}

This section provides results regarding the transmission of domestic and foreign shocks to Ukraine. We calculate GIRFs for Ukraine using several strategies for computing alternative trade-matrices for model solution. First, we analyze the benchmark response of four Ukrainian domestic variables to shocks in domestic output, aggregated global output, and oil prices, using a period-average trade structure as the solution matrix. GIRFs are computed using a bootstrap simulation method that in addition to median GIRF estimates provides information about the statistical significance of responses. Second, we show how the response of Ukrainian output to country-specific foreign shocks has evolved over time as trade linkages have undergone considerable change (see Figure 1). Lastly, in order to understand the importance of indirect propagation channels on Ukraine's sensitivity to foreign shocks, we utilize counterfactual trade matrices for model solution. In particular, we compute GIRFs assuming that Ukraine trades only with a single country or region.

\subsection{The Response to Domestic Output, Global Output, and Oil Price Shocks}

The GVAR model described in the second section is first used to compute GIRFs to a $1 \%$ domestic output and aggregated global output shocks, as well as a $50 \%$ oil price shock. The benchmark simulation employs period-average trade and financial compositions for all of the countries in the panel. Benchmark GIRFs are computed using the bootstrap simulation method which allows identification of the confidence level.

The responses given by the model to a $1 \%$ domestic output shock are largely in line with expectations, see Figure 2. Real activity increases, which, in turn, drives inflation up. Consequently, the interest rate goes up while the exchange rate appreciates. In the long term, the responses are, however, statistically insignificant. This indicates that the GVAR model has a limited ability to explain internal relationships and dynamics for Ukraine. This might be related to the relatively short time period under consideration, especially as it includes several possible structural breaks.

We further explore whether the GVAR can be useful in analyzing the effect of foreign shocks on Ukraine. We compute the aggregated global output shock for the benchmark solution by assuming that the rest of the world is a single region in terms of shock origin. We calculate the rest of the world region by weighting country-specific variables using PPP-adjusted GDP aggregation. The global output shock here is common for all countries except Ukraine. Figure 3 plots the response of the four Ukrainian domestic variables to an aggregated global output shock. A one-percent increase in global output generates a roughly 2-percent increase in Ukrainian output on impact, and about a 3-percent increase over the long-term. An increase in real activity abroad generates additional demand for Ukrainian goods, which stimulates Ukrainian output and slightly raises inflation. Higher inflation and increased exports may lead to the appreciation of the real exchange rate. Meanwhile, the response of the interest rate is negative, which is somewhat counterintuitive, as both output and inflation go up. However, given that Ukraine has been practicing a fixed exchange rate regime, the negative response of the interest rate to a positive global output shock can be explained by the appreciation of the real exchange rate.

Compared to previous studies on Ukraine and other emerging small open economies, our estimates of the output response are relatively large. ${ }^{12}$ This can be explained by the specification of the Ukrainian model, where the lag order for domestic and weekly exogenous variables is not limited to unity. On the one hand, the inclusion of additional lags takes into account delayed macroeconomic effects and provides richer dynamics. On the other hand, the complex structure of the GVAR model can amplify responses via the higherorder transmission channels. Nevertheless, the response of Ukrainian output is statistically significant, with the lower confidence band being higher than 1 percent. The responses of other variables are statistically insignificant, except for

\footnotetext{
${ }^{8}$ For the technical procedure of model estimation, we use an open source Matlab toolbox for modeling GVAR provided by Smith \& Galesi (2014).

${ }_{9}^{9}$ For the technical procedure of model estimation, we to World Bank database for 2000-2016.

${ }^{10}$ The weights used to construct foreign output variables are based on annual bilateral goods trade flows (i.e. exports plus imports in US dollars). The trade data come from the IMF Direction of Trade Statistics database, which provides data on the geographical distribution of countries' exports and imports.

${ }^{11}$ To incorporate financial exposures of CIS economies, the authors use the IMF's Coordinated Portfolio Investment Survey (CPIS), a dataset on the stock of cross-border holdings of equities and debt securities broken down by issuer residence.

12 See, for example, Faryna \& Simola (2018), Feldkircher (2015), Feldkircher \& Korhonen (2014)
} 
the real exchange rate, which appreciates in response to a positive foreign output shock. Our analysis suggests that the GVAR model can be used effectively for studying the response of real activity in Ukraine to foreign output shocks.

Lastly, we compute the GIRFs to a global oil price shock for Ukrainian variables. Given that Ukraine's economy can be characterized as both commodity importing (e.g. energy imports) and commodity exporting (e.g., metals and agriculture exports), the direction of the response to an oil price shock is not straightforward to assess. On the one hand, the increase in energy prices leads to an increase in costs for energy importers and, hence, negatively affects output. On the other hand, oil prices closely correlate with other commodities. Therefore, assuming that the increase in oil prices is associated with increases in prices for other commodities, higher prices should not automatically decrease real output. The aggregated effect, therefore, depends on what channel dominates. In addition, a positive output response of Russia and other trading partners in the $\mathrm{CIS}$ region to an oil price shock may generate additional demand for Ukrainian goods which, in turn, drives Ukrainian output up. Figure 4 plots the response of Ukrainian variables to a $50 \%$ oil price shock together with $90 \%$ confidence bands. The initial response of output is positive (about $4 \%$ ), while the real exchange rate appreciates (about 9\%) with these responses being significant on impact. Long-term responses, however, are insignificant, indicating that the GVAR model is unable to explain the response of Ukraine's economy to commodity price shocks.

Having explored the properties of the benchmark GVAR model with a particular focus on Ukraine, we find that this framework can be useful to understand how foreign output shocks affect Ukrainian real activity. Our estimates can be interpreted in order to measure the response of Ukrainian output to a global recession. In particular, a mild global recession of 1 percent output drop generates a substantial recession of $2 \%$ drop in Ukrainian output on impact and $3 \%$ drop in the long-run. This indicates that Ukrainian economy is particularly sensitive to global shocks.

However, the cross-country transmission of output shocks heavily depend on trade relationships. Recall that foreign output variables for each individual country model are computed using trade-weighted matrices. Therefore and given that the trade composition in Ukraine has been changing considerably over last decades, we further analyze the response of Ukraine to country-specific foreign output shocks and how it has been changing over time.

\subsection{Evolution of Responses to Country-Specific Foreign Output Shocks}

We compute GIRFs for Ukraine to 1 percent output shocks in the US, euro area, Russia, China, CEE, and $\mathrm{CIS}$ region excluding Russia. ${ }^{13}$ All these countries or regions have been important trade partners for Ukraine over the last few decades. The GVAR model in this paper performs fairly well in terms of dealing with cross-country residual correlation which allows us to identify country-specific shocks. However, the relatively high number of individual country models with first order serial correlation limits our ability to identify variable-specific structural shocks. Therefore, in our further analysis we are able to distinguish between shocks to foreign output across countries, while variable-specific structural identification is limited. ${ }^{14}$ Given that our model utilizes timevarying trade matrices, we compute GIRFs to output shocks in all the above-mentioned economies for each year starting from 2000 until 2016. Figure 5 shows time-varying long-term responses for Ukraine. ${ }^{15}$

In terms of the degree of sensitivity, Ukraine is highly sensitive to output shocks in the US. A one-percent shock to output in the US increases Ukrainian output by about $2.2 \%$. Although the share of the US in the trade composition in Ukraine is relatively moderate (about $5 \%$ ), the importance of the US can be explained by its dominance in the global economy in general. It seems that the response to the shocks originating in the US has been slightly declining over the last two decades (2.4\% in 2000 compared to $2.1 \%$ in 2016).

The high sensitivity of Ukraine to a euro area shock, in turn, is mainly explained by tight trade relationships (about $25 \%$ of Ukraine's total trade, see Figure 1). The response to a euro area shock has been steadily increasing from $0.5 \%$ in 2000 to $1.7 \%$ in 2016 . This is partly due to the increased significance of the euro area as a trading partner for Ukraine, but, as argued in Faryna \& Simola (2018), is also due to changes in the trade compositions of other countries, which have made the euro area more powerful in terms of the shock transmission.

The response of Ukraine to Russian output shocks is relatively high as well. A one-percent increase in Russian output translates to an increase of about $1.7 \%$ in Ukrainian output. Ukraine's sensitivity to Russian shocks has somewhat decreased since the start of the geopolitical conflict between Russia and Ukraine in 2014, but remains relatively high - despite the considerable drop in the trade relationships between the countries. This can be explained by the importance of the Russian economy to other emerging economies (e.g., CIS and CEE) to which Ukraine has shifted its trade recently.

Despite the growing importance of China on the global stage, as well as in the trade composition of Ukraine, the Ukrainian economy's response to Chinese output shocks remains moderate. A one-percent increase of output in China is associated with an increase of about $0.4 \%$ in Ukrainian output in 2000, and about $0.5 \%$ in 2016 . Noteworthy, the sensitivity of Ukraine to Chinese shocks is higher than for several other countries, as shown in Faryna \& Simola (2018).

The CEE and CIS economies have always been important trade partners for Ukraine. The trade share of CEE and CIS increased from about $10 \%$ in 2000 to $15 \%$ for CEE in 2016, and from $6 \%$ to $9 \%$, for the CIS. The response to a one-percent shock in the CIS translates to about a $0.5 \%$ increase in output in Ukraine, with that response having slightly decreased in recent years. The effect of a one-percent output shock in CEE, in turn, has rapidly increased - from $0.3 \%$ to $0.6 \%$ - in recent years, which can be explained by increases in trade between Ukraine and CEE.

\footnotetext{
${ }^{13}$ CEE and CIS variables were computed using PPP-adjusted GDP aggregation. CEE region comprises five countries: Bulgaria, Czech Rep., Hungary, Poland, Romania. CIS region excludes Russia and comprises four countries: Azerbaijan, Belarus, Georgia, Kazakhstan.

${ }^{14}$ For example, we are not able to treat foreign output shocks as demand shocks.

${ }^{15} \mathrm{GIRFs}$ here are calculated at the 30 th period of response.
} 
To sum up, Ukraine is particularly sensitive to output shocks in the US, the euro area, and Russia, while the response to euro area shocks has been steadily increasing over the last couple of decades. The response to other emerging markets remains moderate and stable, except of the effect from CEE, to which Ukraine has rapidly shifted its trade in recent years.

\subsection{Counterfactual Scenarios on Alternative Trade Compositions}

In the previous subsection we showed that changes in trade composition have influenced the sensitivity of the Ukrainian economy to foreign output shocks. However, the changes in the Ukrainian responses seem not to be fully explained by changes in the trade structure of Ukraine. Therefore, we further develop a strategy based on counterfactual scenarios of trade composition in order to evaluate the relative importance of direct and indirect trade channels in the Ukrainian economy's sensitivity to foreign shocks.

For this purpose, we assume that Ukraine trades only with a single economy (country or region) while the rest of the world keeps its trade composition unchanged. Technically, we adjust the way foreign-specific variables are calculated for model solution. In particular, in the equation for foreign variables, $X_{U K R t}^{*}=\sum_{j=1}^{N} \omega_{U K R j} X_{j t}$, we change the vector of trade weights for Ukraine $\omega_{U K R j}$ so that it contains one element, which equals "1", and other elements which equal " 0 ". If $\omega_{U K R}(j)=1$, Ukraine has full trade linkage with country $j$. If $\omega_{U K R}(j)=0$, Ukraine has no trade linkage with country j. In addition, we assume that Ukraine has no effect on other countries. We normalize trade and financial weights so that the share of Ukraine equals zero for all countries in the panel. Given that Ukraine's original trade share for the rest of the world is very small, this assumption has almost no effect on the amplification of shocks in the model. Financial linkages remain unchanged for the world economy, as well as for Ukraine.

The analysis can be useful for identifying how foreign output shocks affect Ukraine through direct and indirect trade channels. In particular, a foreign shock to a specific country can affect other countries through their direct trade relationships. A positive shock to a trading-partner economy, e.g. the euro area, creates additional demand for Ukrainian goods, which stimulates exports, and hence raises production and output. In addition, given the complex structure of the GVAR model, which takes into account dynamic and contemporaneous cross-country interdependencies, directly-affected countries can also transmit such shocks further to their trading partners. For example, a positive shock in the euro area creates additional demand for goods not only in Ukraine, but also in other economies linked by bilateral trade, e.g. CEE, the CIS, Russia. These economies, in turn, have an additional effect on Ukraine through the demand channel. Note also that the response to a rise in foreign output is not necessarily positive. If countries gain from bilateral trade, the response of output is expected to be positive. However, if countries face global competition, the response might be negative. Therefore, the general effect of direct and indirect channels depends on the composition of global trade.

A GVAR model can be a useful tool for decomposing direct and indirect channels and illustrating the importance of indirect effects that are not easily identified otherwise. For different counterfactual scenarios, we compute GIRFs for Ukrainian output in response to country-specific output shocks over the long-term, see Figure 6. Each panel corresponds to the response of output in Ukraine to foreign output shocks in the US, the euro area, CEE, China, Russia, and the CIS. Each bar, in turn, shows the response of output in Ukraine in a scenario in which Ukraine trades only with the corresponding economy marked on the x-axis. The baseline response corresponds to the scenario in which trade-weighted solution matrices are computed as periodaverage trade compositions for each country.

We can note two things from Figure 6, with the example of a shock originating in the US economy in the upper left corner. First, compared to the baseline, the response of the Ukrainian output to a shock in US output is higher when Ukraine trades only with the US. This can be expected, as in this case the weight of the US in the foreign output variable is much higher than in the baseline, exceeding the output effects coming from other countries. Second, we can see that an output shock originating in the US has a relatively strong effect on Ukrainian output, even if Ukraine is not directly trading with the US. If Ukraine is trading, e.g., only with the EMU area, the response of Ukrainian output to a shock originating in the US is nearly as strong as in the baseline, as the US shock increases output and demand in the EMU area, hence supporting Ukrainian exports and output.

Note that our decomposition does not fully distinguish between direct and indirect bilateral trade effects. In particular, even if Ukraine trades only with a shockoriginating economy, higher-order spillover channels are enabled. Other affected countries can spill back to a shockoriginating economy and have a third-round effect on Ukraine. While the baseline response is the sum of direct and indirect effects given the average trade structure over time, responses under counterfactual scenarios do not measure the direct effect from the baseline response. In contrast, under the counterfactual scenario, we increase the relative weight of the direct effect so that it can be higher than the baseline response if the sensitivity to a shockoriginating economy is also relatively higher. Nevertheless, this analysis can indicate whether the difference between responses in various scenarios changes, and whether the sensitivity to country-specific shocks depends on direct bilateral channels, or if it remains stable even if countries have no direct linkages.

This analysis suggests that the sensitivity of Ukraine to output shocks in the US does not solely depend on bilateral trade flows with the US. In particular, even if Ukraine only trades with other countries, the response to shocks in the US does not change considerably. Meanwhile, if Ukraine trades only with the US, the response of Ukrainian output increases from $2.2 \%$ (baseline) to $2.6 \%$. This indicates the dominant role of the US in the world and the existence of strong indirect channels for the transmission of its shocks.

We get similar results for sensitivity to output shocks in the euro area. Ukraine's response to a euro area output shock increases form 1.5\% (baseline) to 1.9\% if Ukraine trades only with the euro area. However, if Ukraine only trades with other countries, the response to a euro area shock does not drop considerably. Similar to the US economy, the euro area can play an important role for other countries and affect 
Ukraine through indirect trade channels.

Ukraine's sensitivity to the Russian economy seems to depend on both direct and indirect channels. Under full trade linkage with Russia, Ukrainian sensitivity increases from $1.4 \%$ (baseline) to $1.8 \%$. Meanwhile, the response decreases to about $1 \%$ if Ukraine only trades with other countries. Although the direct trade channel seems to be crucial for the transmission of Russian shocks to Ukraine, the indirect channel should not be ignored: Ukraine also has tight trade relationships with the CIS region and other economies that are sensitive to Russian shocks.

The response of Ukraine to foreign shocks in China, CEE, and the CIS seems to depend mainly on direct bilateral trade linkages. In particular, under full trade linkage with China, CEE, and the CIS, Ukraine's response increases from $0.6 \%$, $0.5 \%$, and $0.4 \%$ (baseline) respectively, to $1.2 \%, 1.6 \%$, and $0.8 \%$. If Ukraine trades with other countries, those responses decrease or remain the same. This suggests that Ukraine's response to shocks from emerging economies are not amplified much through indirect trade channel.

The analysis shows that especially in the case of shocks from the US and the euro area, indirect effects are also very important - even beyond direct bilateral trade linkages. Ukraine's sensitivity to shocks from most emerging economies mainly depends on bilateral trade linkages, but indirect channels can also play a role, although these are more moderate.

\section{CONCLUSIONS}

Being a small open emerging economy with tight trade linkages to advanced economies and the emerging world, Ukraine is sensitive to foreign shocks. In order to explore the transmission of country-specific foreign shocks to Ukraine, we employ a global vector auto regressive model that consists of 30 economies, including Ukraine and its major trading partners. The estimated individual country models are combined by trade and financial linkages which determine the role of each country in the transmission of international shocks.

We compute Generalized Impulse Response Functions for Ukraine using a bootstrap method and find that the model can be effectively used to assess the Ukrainian economy's response to foreign output shocks. In particular, the results suggest that a $1 \%$ shock to aggregated global output translates to about 3\% increase in Ukrainian output in the long-term, with that response being statistically significant at $90 \%$ confidence level.

We then compute time-varying responses of Ukraine to country-specific shocks to foreign output in the US, the euro area, Russia, China, and the CEE and CIS regions. Our findings indicate that the US plays a dominant role for Ukraine, despite having a relatively low share in Ukrainian trade structure. A mild recession in the US of a $1 \%$ drop of output generates a substantial recession in Ukraine of about $2.2 \%$. The sensitivity of Ukraine to output shocks in the euro area and Russia is high as well, which can be explained by the strong trade links between these countries. A similar drop of output in the euro area and Russia translates to a drop of about $1.7 \%$ in output in Ukraine. The response to euro area shocks, however, has increased considerably since the early 2000s, which does not tally with changes in Ukraine's trade structure. Meanwhile, the response to shocks in Russia has sharply decreased since the start of the geopolitical conflict in 2014 and the imposition of trade restrictions by both countries. The sensitivity to output shocks in China, the $\mathrm{CIS}$, and CEE remains relatively lower. The same $1 \%$ drop of output in CEE, China, and CIS leads to a decline of about $0.4 \%$ in output in Ukraine. However, since recessions tend to be much deeper in Russia, CEE, and the CIS, the general effects of a recession in these countries or regions can be painful for Ukraine.

In order to illustrate the importance of indirect trade linkages in the propagation of foreign shocks, we solve the GVAR model under counterfactual scenarios for Ukrainian trade composition. We assume that Ukraine trades only with a single country, and compute impulse responses to output shocks in the above-mentioned economies. We find that output shocks in advanced economies, especially the US, have strong indirect effects on Ukraine, even if direct bilateral trade is small, as they affect other countries that trade more with Ukraine. For emerging-economy shocks, Ukraine's response mainly depends on the direct trade linkages, while indirect effects are not very important. In particular, the response of output in Ukraine decreases considerably if bilateral trade with shock-originating economies is limited. 


\section{REFERENCES}

Alturki, F., Espinosa-Bowen, J., Ilahi, N. (2009). How Russia affects the neighborhood: trade, financial and remittance channels. IMF Working Paper, 09/277. International Monetary Fund. https://doi.org/10.5089/9781451874228.001

Beckmann, E., Fidrmuc, J. (2013). Exchange rate passthrough in CIS countries. Comparative Economic Studies, 55(4), 705-720. https://doi.org/10.1057/ces.2013.8

Canova, F., Ciccarelli, M. (2013). Panel vector autoregressive models: A survey. European Central Bank Working Paper Series, 1507. European Central Bank. Retrieved from https://www.ecb.europa.eu/pub/pdf/scpwps/ecbwp1507.pdf

Chudik, A., Pesaran, M. H. (2013). Econometric analysis of high dimensional VARs featuring a dominant unit. Econometric Reviews, 32(5-6), 592-649. https://doi.org/10.1080/07474938.2012.740374

Comunale, M., Simola, H. (2018). The pass-through to consumer prices in $\mathrm{CIS}$ economies: The role of exchange rates, commodities and other common factors. Research in International Business and Finance, 44, 186-217. https://doi.org/10.1016/j.ribaf.2017.07.076

Dees, S., di Mauro, F., Pesaran, M. H., Smith, L. V. (2007). Exploring the international linkages of the euro area: A global VAR analysis. Journal of Applied Econometrics, 22(1), 1-38. https://doi.org/10.1002/jae.932

Dreger, C., Fidrmuc, J. (2011). Drivers of exchange rate dynamics in selected CIS Countries: Evidence from a Factor-Augmented Vector Autoregressive (FAVAR) Analysis. Emerging Markets Finance and Trade, 47(4), 49-58. https://doi.org/10.2753/ree1540-496×470403

Faryna, O. (2016a). Exchange rate pass-through and cross-country spillovers: some evidence from Ukraine and Russia. BOFIT Discussion Paper, No. 14. Helsinki: Bank of Finland. https://helda.helsinki.fi/bof/bitstream/ handle/123456789/14368/dp1416.pdf

Faryna, O. (2016b). Nonlinear exchange rate passthrough to domestic prices in Ukraine. Visnyk of the National Bank of Ukraine, 236, 30-42. National Bank of Ukraine. https://doi.org/10.26531/vnbu2016.236.030

Faryna, O., Simola, H. (2018). The Transmission of International Shocks to CIS Economies: A Global VAR Approach. NBU Working Paper, 4/2018. https://bank.gov.ua/doccatalog/document?id=77136251
Feldkircher, M. (2015). A global macro model for emerging Europe. Journal of Comparative Economics, 43(3), 706-726. https://doi.org/10.1016/j.jce.2014.09.002

Feldkircher, M. Korhonen, I. (2014). The rise of China and its implications for emerging markets - evidence from a GVAR model. Pacific Economic Review, 19(1), 61-89. https://doi.org/10.1111/1468-0106.12052

Galesi, A., Lombardi, M. J. (2009). External shocks and international inflation linkages: a global analysis. European Central Bank Working Paper Series, 1062. Frankfurt am Main: European Central Bank. https://www.ecb.europa.eu/pub/pdf/scpwps/ecbwp1062.pdf

Hajek J., Horvath R. (2018). International spillovers of (un)conventional monetary policy: the effect of the ECB and the US Fed on non-euro EU countries. Economic Systems, 42(1), 91-105. https://doi.org/10.1016/j.ecosys.2017.10.001

Harahap, B. A., Bary, P., Panjaitan, L. N., Satyanugroho, R. (2016). Spillovers of United States and people's republic of China shocks on small open economies: the case of Indonesia. ADBI Working Paper Series, 616. https://www.adb.org/sites/default/files/publication/213516/ adbi-wp616.pdf

Lepushynskyi, V. (2015). A strategic document on monetary policy for the period of the inflation targeting adoption in Ukraine. Visnyk of the National Bank of Ukraine, 233, 24-38. https://doi.org/10.26531/vnbu2015.233.024

Pesaran, M.H.,Shin, Y.(1998). Generalized impulse response analysis in linear multivariate models. Economics Letters, 58(1), 17-29. https://doi.org/10.1016/s0165-1765(97)00214-0

Pesaran, M. H., Schuermann, T., Weiner, S. M. (2004). Modelling regional interdependencies using a global error-cointegration macro-econometric model. Journal of Business \& Economic Statistics, 22, 129-162. https://doi.org/10.1198/073500104000000019

Smith, L. V., Yagamata, T. (2011). Firm level return-volatility analysis using dynamic panels. Journal of Empirical Finance, 18(5), 847-867. https://doi.org/10.1016/j.jempfin.2011.07.001

Smith, L. V., Galesi, A. (2014). GVAR Toolbox 2.0. Retrieved from https://sites.google.com/site/gvarmodelling/ gvar-toolbox 


\section{APPENDIX A. TABLES}

Table 1. Description of the GVAR Model: Main Features and Variables

\begin{tabular}{|c|c|}
\hline Time coverage & 2001Q1 - 2016Q4 \\
\hline Countries and regions & $\begin{array}{l}\text { Ukraine } \\
\text { USA } \\
\text { China } \\
\text { Russia } \\
\text { Euro area (block with 12-19 countries): Austria, Belgium, Finland, France, Germany, } \\
\text { Greece, Ireland, Italy, Luxembourg, Netherlands, Portugal, Spain (2001-2006); } \\
\text { plus Slovenia (2007), Cyprus, Malta (2008), Slovakia (2009), Estonia (2011), Latvia (2014), } \\
\text { Lithuania (2015) } \\
\text { CIS (4 countries): Azerbaijan, Belarus, Georgia, Kazakhstan. } \\
\text { Note that Georgia left the organization in 2008 but otherwise has tight relations with } \\
\text { countries in the region. } \\
\text { CEE (5 countries): Bulgaria, Czech Rep., Hungary, Poland, Romania) } \\
\text { Rest of the World (16 separate countries): Australia, Brazil, Canada, Chile, Denmark, } \\
\text { Iceland, India, Indonesia, Japan, Korea, Mexico, New Zealand, Norway, Sweden, } \\
\text { Turkey, UK }\end{array}$ \\
\hline $\begin{array}{l}\text { Variables } \\
\text { (Sources: IMF IFS, OECD, } \\
\text { National sources) }\end{array}$ & $\begin{array}{l}y=\text { real GDP, index (average of } 2010=100 \text { ), seasonally adjusted, in logs } \\
d p=\text { consumer price inflation, seasonally adjusted, first log-differences } \\
e=\text { real exchange rate (nominal exchange rate w.r.t USD deflated by domestic CPI), } \\
\text { index (average of } 2010=100 \text { ), in logs, (up - depreciation) } \\
r=\text { nominal short-term interest rate, typically 3-month or 90-day interbank interest } \\
\text { rate } \\
f=\text { Brent oil price, index (average of } 2010=100 \text { ), seasonally adjusted, in logs }\end{array}$ \\
\hline $\begin{array}{l}\text { Weights } \\
\text { (Sources: IMF DOTS, } \\
\text { IMF CPIS) }\end{array}$ & $\begin{array}{l}\text { Trade: shares of partner countries in total goods trade (sum of exports and imports) } \\
\text { Financial: shares of partner countries in the stock of cross-border holdings of equities } \\
\text { and long- and short-term debt securities }\end{array}$ \\
\hline \multicolumn{2}{|c|}{ Diagnostic test (excluding Ukraine) } \\
\hline ADF Stationarity & $\begin{array}{l}36 \text { out of } 202 \text { series }-I(0) \\
176 \text { out of } 202 \text { series }-I(1)\end{array}$ \\
\hline Lag length & $p=1$ and $q=1$ (degrees of freedom considerations) \\
\hline Cointegration & $\begin{array}{l}\text { Trace statistics for rank selection ( } 1 \text { to } 3 \text { cointegration equations) } \\
\text { LR test for the type of deterministic components (cases II-IV) }\end{array}$ \\
\hline Weak exogeneity & 69 out of 84 variables (F-test at 5\% significance level) \\
\hline Residual serial correlation & No residual serial correlation for 83 out of 115 equations (F-test at $5 \%$ significance level) \\
\hline
\end{tabular}


Table 2. Diagnostic Tests for Individual VECMX* Model for Ukraine

ADF stationarity test

\begin{tabular}{lccccccc}
\hline & $\mathrm{y}$ & $\mathrm{dp}$ & $\mathrm{e}$ & $\mathrm{r}$ & $\mathrm{y}^{*}$ & $\mathrm{r}^{*}$ & $\mathrm{f}$ \\
\hline levels & -1.86 & $-3.16^{*}$ & -0.89 & $-2.99^{*}$ & -2.35 & -1.84 & -0.98 \\
(CV) & $(-3.45)$ & $(-2.89)$ & $(-3.45)$ & $(-2.89)$ & $(3.45)$ & $(-3.45)$ & $(-3.45)$ \\
first differences & $-4.16^{*}$ & $-5.67^{*}$ & $-4.52^{*}$ & $-7.20^{*}$ & $-3.29^{*}$ & $-3.61^{*}$ & $-5.59^{*}$ \\
(CV) & $(-2.89)$ & $(-2.89)$ & $(-2.89)$ & $(-2.89)$ & $(-2.89)$ & $(-2.89)$ & $(-2.89)$ \\
\hline
\end{tabular}

Lag order selection (AIC)

\begin{tabular}{ccccc}
\hline$q \backslash p$ & 1 & 2 & 3 & 4 \\
\hline 1 & -287.0 & -288.0 & -283.2 & $-300.5^{*}$ \\
2 & -288.9 & -286.4 & -280.1 & -298.0 \\
3 & -281.9 & -279.9 & -274.1 & -295.6 \\
4 & -278.5 & -277.4 & -273.6 & -297.9 \\
\hline
\end{tabular}

Trace statistics for cointegration rank order selection

\begin{tabular}{ccccc}
\hline$H 0: r=0$ & $H 0: r=1$ & $H 0: r=2$ & $H 0: r=3$ & $\begin{array}{c}\text { Selected } \\
\text { rank }\end{array}$ \\
$H 1: r \geq 1$ & $H 1: r \geq 2$ & $H 1: r \geq 3$ & $H 1: r \geq 4$ & 4 \\
\hline 134.10 & 77.20 & 43.02 & 13.81 & 4 \\
\hline
\end{tabular}

Likelihood ratio test on deterministic components in the cointegration equations

\begin{tabular}{lccc}
\hline & HO: Case III & HO: Case II & $\begin{array}{c}\text { Selected } \\
\text { case }\end{array}$ \\
\hline L1: Case IV & 10.54 & 10.51 & IV \\
(CV) & $(-3.84)$ & $(-12.59)$ & \\
\hline
\end{tabular}

Final VECMX* specification

\begin{tabular}{cccccc}
\hline $\begin{array}{c}\text { Domestic } \\
\text { variables }\end{array}$ & $\begin{array}{c}\mathrm{p} \\
\text { order }\end{array}$ & $\begin{array}{c}\text { Foreign } \\
\text { variables }\end{array}$ & $\begin{array}{c}\mathrm{q} \\
\text { order }\end{array}$ & $\begin{array}{c}\text { Cointegration } \\
\text { rank }\end{array}$ & Cointegration case \\
\hline $\mathrm{y}, \mathrm{dp}, \mathrm{e}, \mathrm{r}$ & 4 & $\mathrm{y}^{*}, \mathrm{r}^{*}, \mathrm{f}^{*}$ & 1 & 1 & $\mathrm{IV}$ \\
\hline
\end{tabular}

Note: final rank of cointegration was reduced to ensure stable persistence profile.

Test for Serial correlation of the VECMX* residuals

\begin{tabular}{ccccc}
\hline F crit. 0.05 & $y$ & $p$ & $e$ & $r$ \\
\hline 2.61 & $1.66^{*}$ & $0.43^{*}$ & $2.54^{*}$ & $0.40^{*}$ \\
\hline
\end{tabular}

Test for weak exogeneity of foreign-specific variables

\begin{tabular}{ccccc}
\hline F crit. 0.05 & $y^{*}$ & $r^{*}$ & $f$ & $r$ \\
\hline 4.03 & $0.03^{*}$ & $0.14^{*}$ & $2.02^{*}$ & $0.40^{*}$ \\
\hline
\end{tabular}




\section{APPENDIX B. FIGURES}
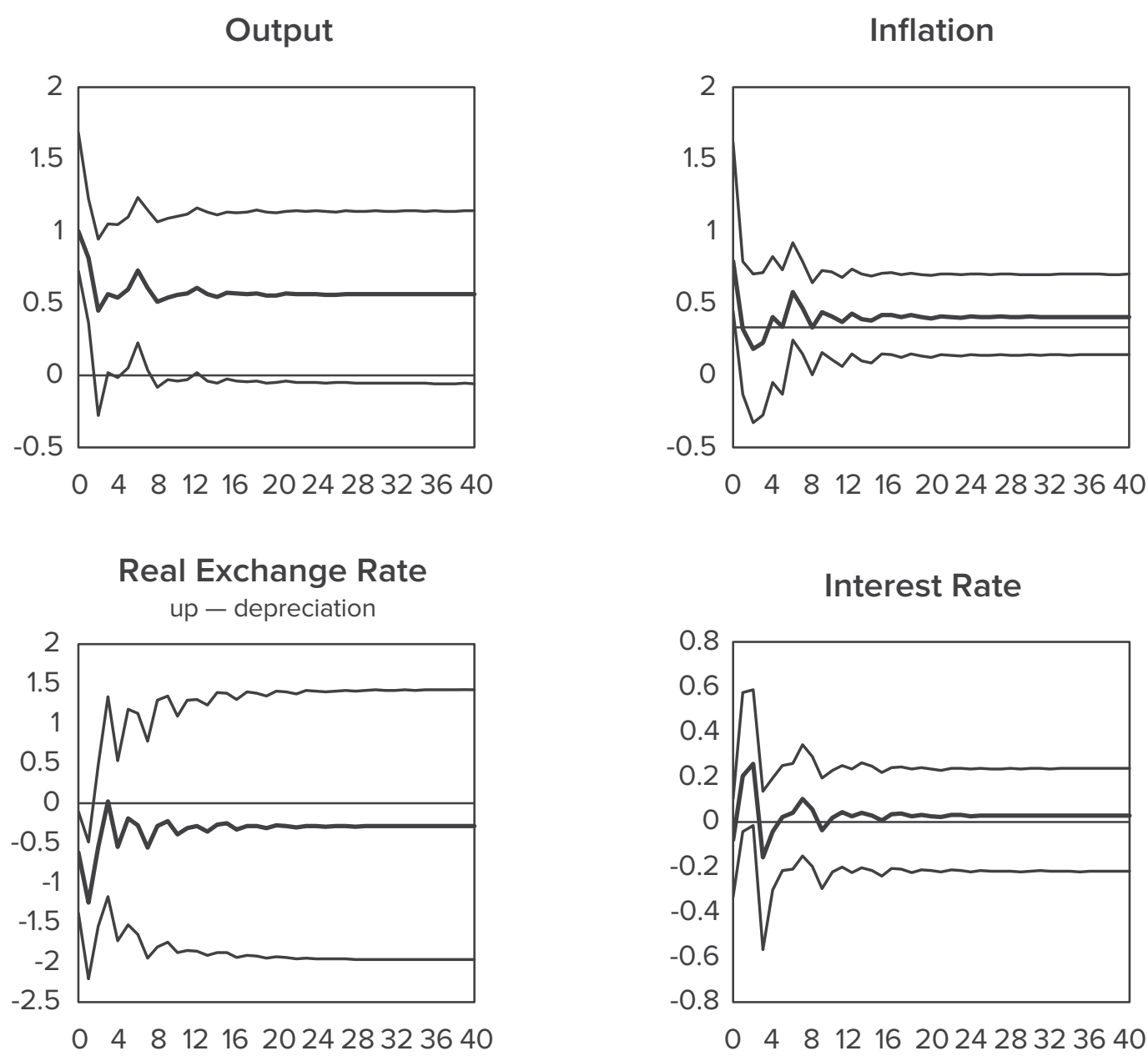

Figure 2. Response of Ukrainian Macroeconomic Variables to $1 \%$ Shock to Domestic Output with 90\% Confidence Bands (in percent). 

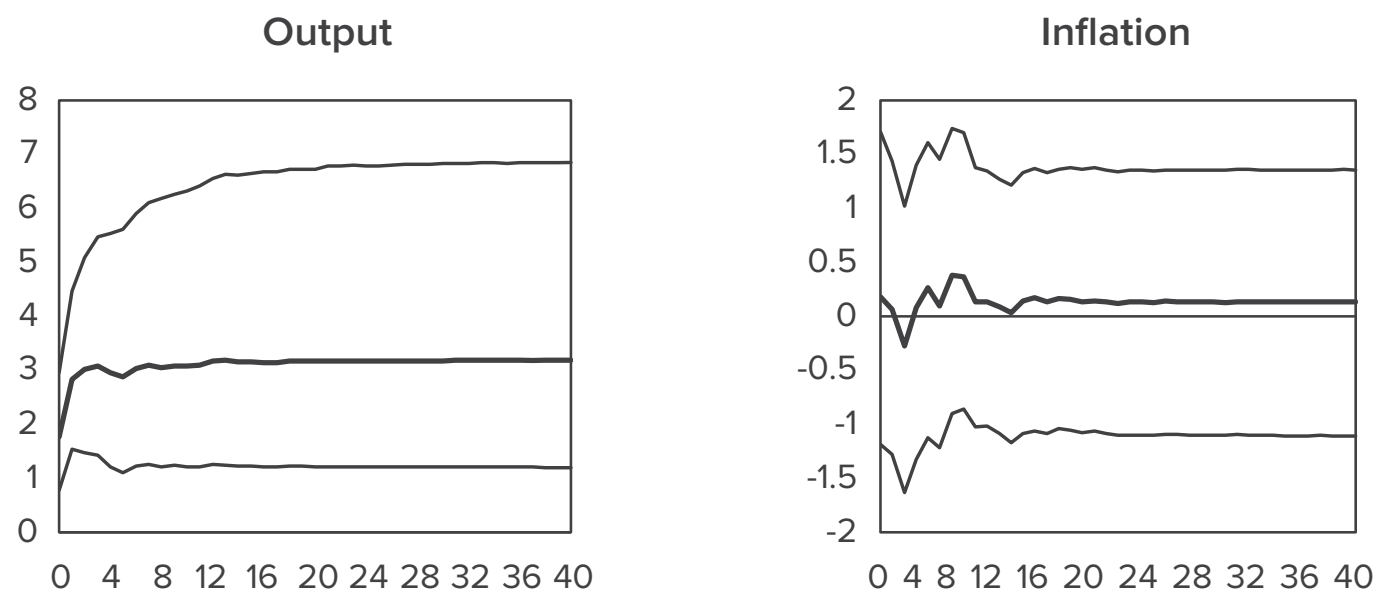

\section{Real Exchange Rate}

up - depreciation

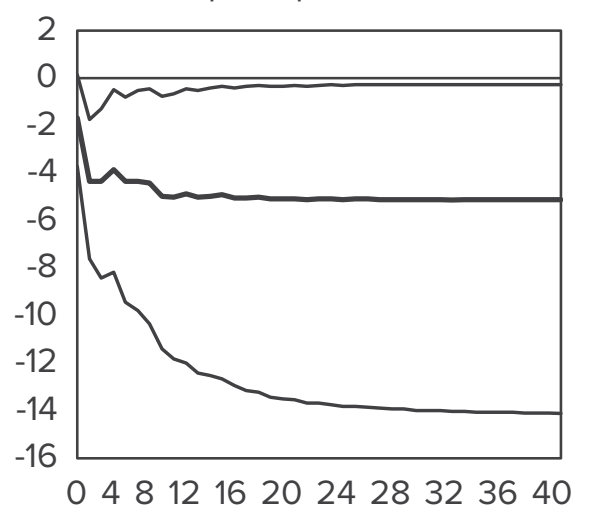

\section{Interest Rate}

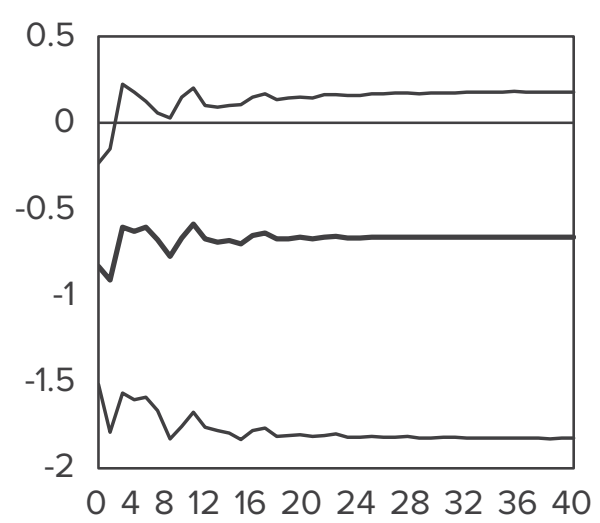

Figure 3. Response of Ukrainian Macroeconomic Variables to $1 \%$ Shock to Aggregated Global Output with $90 \%$ Confidence Bands (in percent). 

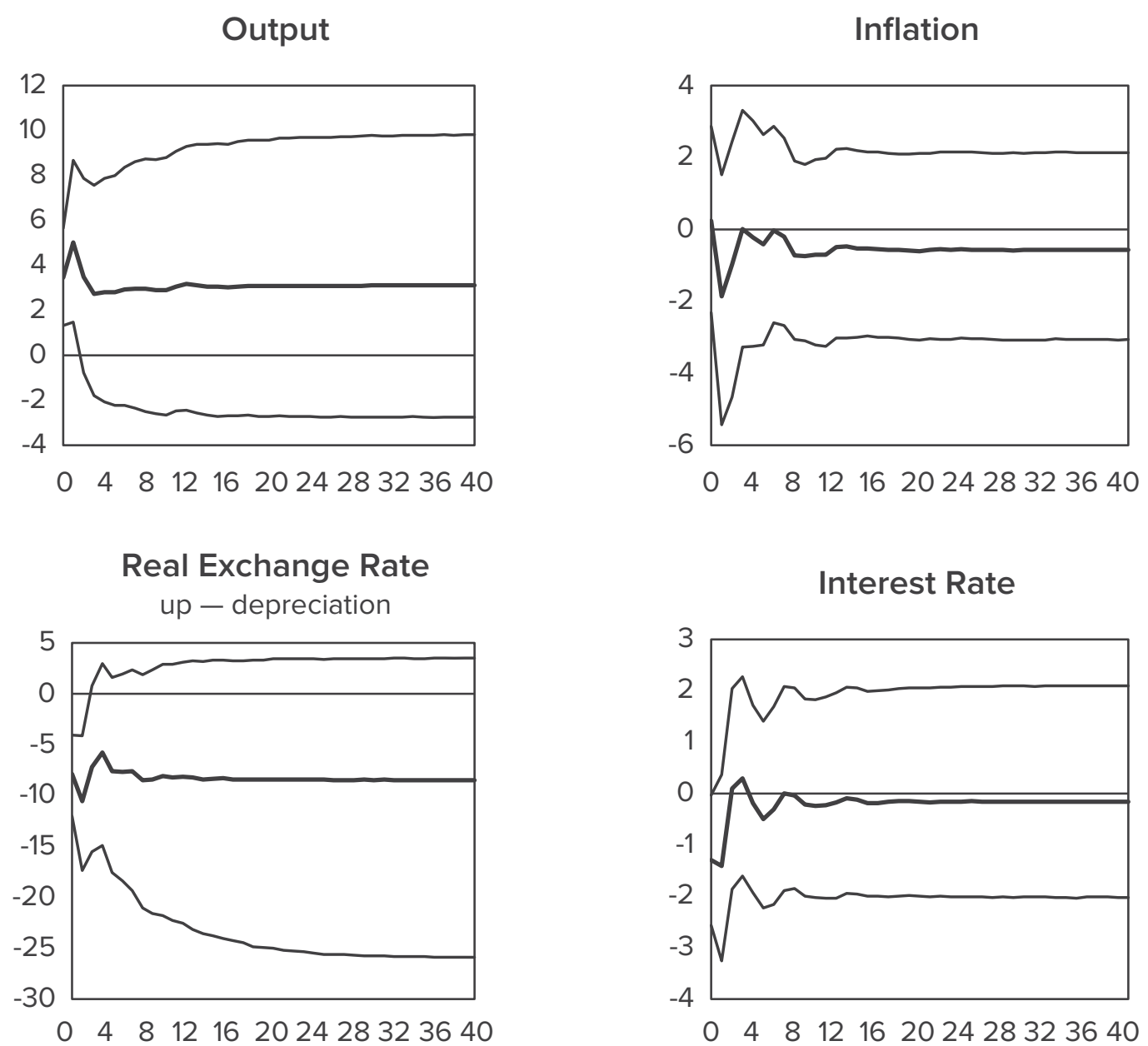

Figure 4. Response of Ukrainian Macroeconomic Variables to 50\% Shock to Oil Price with 90\% Confidence Bands (in percent) 

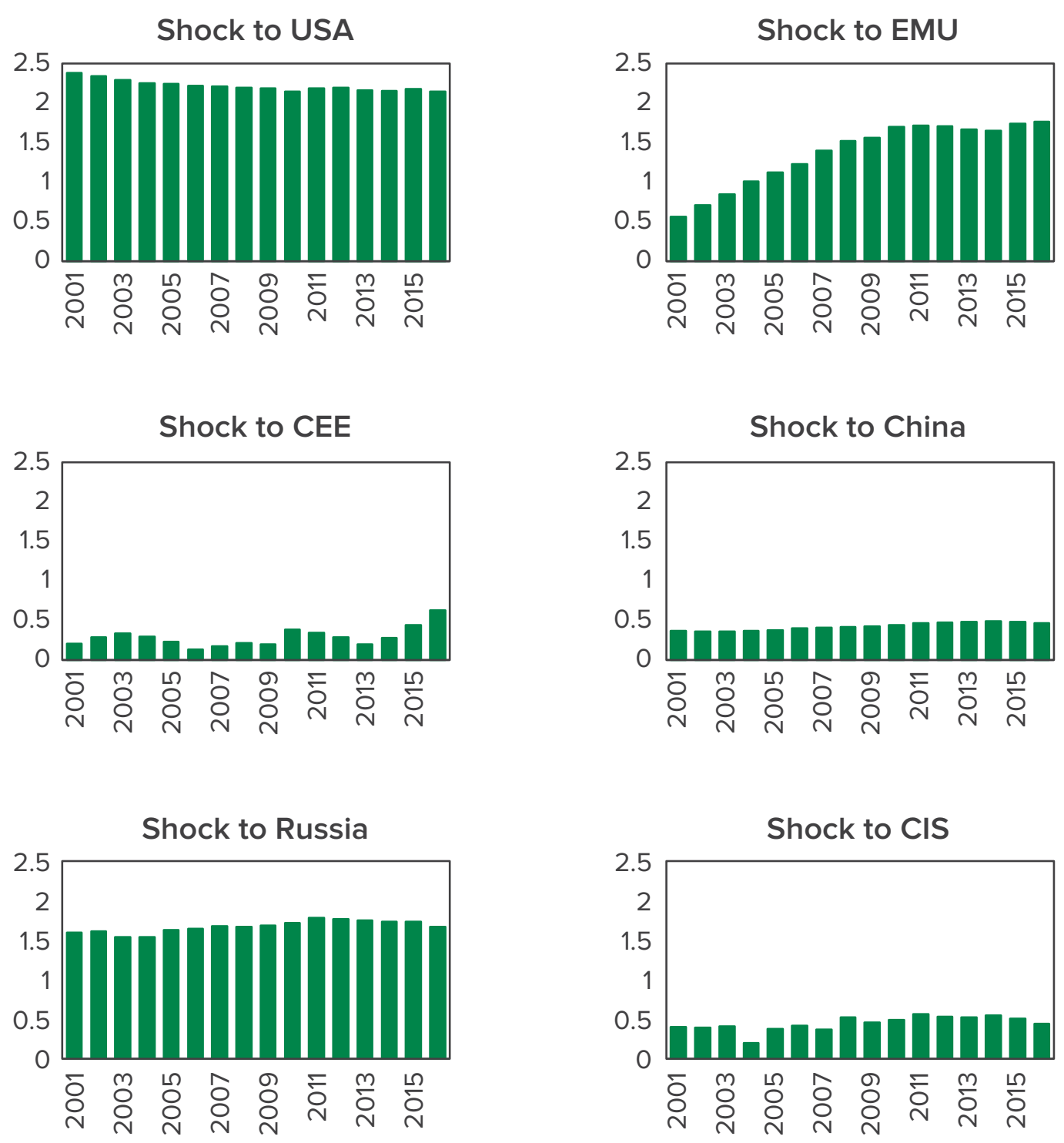

Figure 5. Time-Varying Response of Ukrainian Output to $1 \%$ shock to Foreign Output in the USA, EMU, CEE, China, Russia, and CIS (in percent).

Note: time-varying responses are computed using year-specific trade and financial matrices. 
Shock to USA

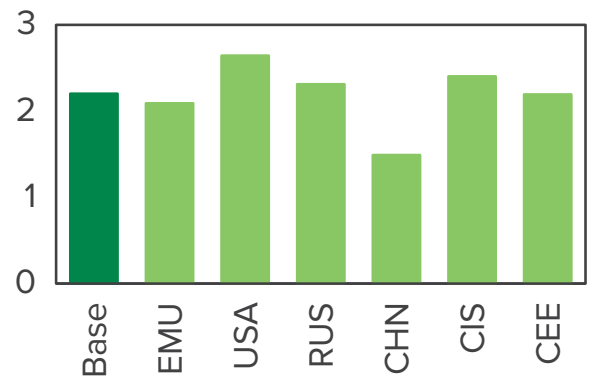

Shock to CEE

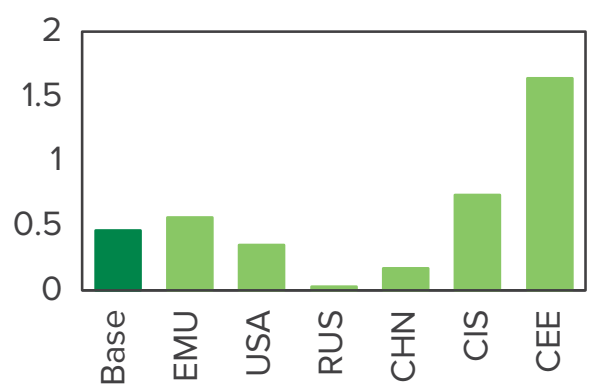

Shock to Russia

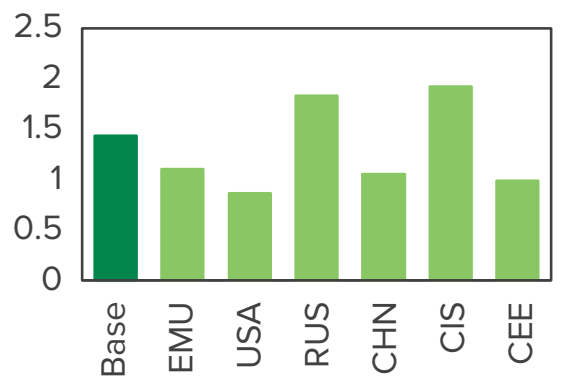

Shock to EMU

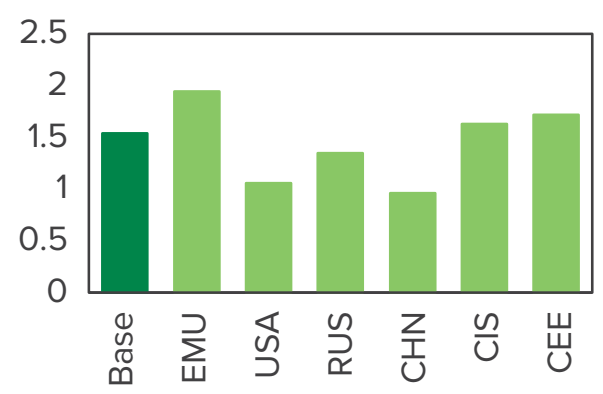

Shock to China

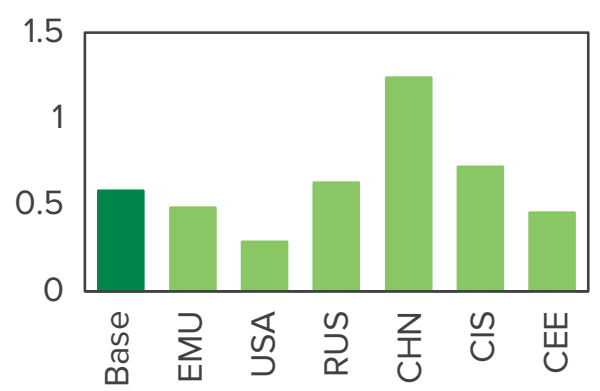

Shock to CIS

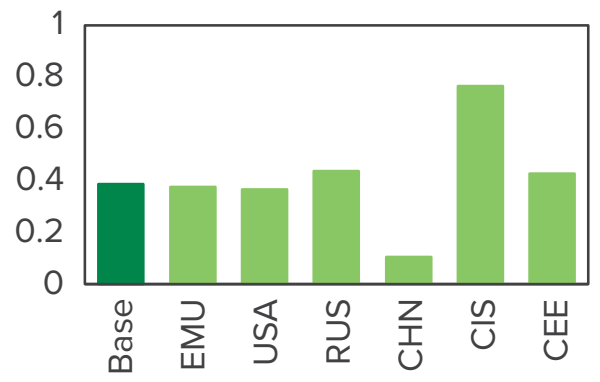

Figure 6. Response of Ukrainian Output to $1 \%$ Shock to Foreign Output in the USA, EMU, CEE, China, Russia, and CIS Under Assumption of Full Trade Linkage to Corresponding Economies (in percent).

Note: responses are computed using counterfactual trade matrices where Ukraine trades only with a single country marked on the $x$-axis. 